\title{
Management of low back pain in primary care prior to multidisciplinary functional restoration: A retrospective study of 72 patients
}

\section{Parcours de soins primaires des lombalgiques chroniques avant prise en charge multidisciplinaire en restauration fonctionnelle : étude rétrospective de 72 patients}

\author{
C. Bouton ${ }^{\mathrm{a}, \mathrm{b}}$, G. Roche ${ }^{\mathrm{a}, \mathrm{c}}$, Y. Roquelaure ${ }^{\mathrm{a}, \mathrm{d}}$, E. Legrand ${ }^{\mathrm{e}, \mathrm{f}}$, D. Penneau-Fontbonne ${ }^{\mathrm{a}, \mathrm{d}}$, \\ V. Dubus ${ }^{c}$, L. Bontoux ${ }^{c}$, J.-F. Huez ${ }^{b}$, P. Rucay ${ }^{a, d}$, E. Parot-Shinkel ${ }^{\text {a,g }}$, \\ S. Fanello ${ }^{\mathrm{a}, \mathrm{g}}$, I. Richard ${ }^{\mathrm{a}, \mathrm{c}, *}$ \\ ${ }^{a}$ Laboratoire d'ergonomie, epidémiologie et santé au travail, faculté de médicine, université d'Angers, rue Haute-de-Reculée, \\ 49045 Angers cedex, France \\ ${ }^{\mathrm{b}}$ Département de médecine générale, faculté de médecine, université d’Angers, rue Haute-de-Reculée, 49045 Angers cedex, France \\ ${ }^{\mathrm{c}}$ Département de médecine physique et réadaptation adulte, CHU-CRRRF, 3, rue des Capucins, BP 40329, 49103 Angers cedex 02, France \\ 'Département de médecine du travail, faculté de médecine, université d'Angers, rue Haute-de-Reculée, 49045 Angers cedex, France \\ ${ }^{\mathrm{e}}$ Rhumatologie, CHU, 4, rue Larrey, 49933 Angers cedex, France \\ ${ }^{\mathrm{f}}$ Inserm EMI 0335, faculté de médecine, université d'Angers, rue Haute-de-Reculée, 49045 Angers cedex, France \\ ${ }^{\mathrm{g}}$ Département de santé publique, faculté de médecine, université d'Angers, rue Haute-de-Reculée, 49045 Angers cedex, France
}

Received 14 August 2008; accepted 14 August 2008

\begin{abstract}
Objective. - Chronic low back pain is a major socioeconomic health issue, due to the high direct (healthcare) and indirect (sick leave) costs. The aim of the present study was to describe the primary care management of low back pain patients prior to their inclusion in a multidisciplinary functional restoration network.

Methods. - A descriptive, retrospective, questionnaire-based survey of the general practitioners dealing with 72 low back pain patients.

Results. - Patients had been monitored by their general practitioner for an average of four years, with a mean frequency of eight appointments per year per patient. Ninety-three percent and $60 \%$ of the patients had been referred to a rheumatologist and a surgeon, respectively. Ninety-eight percent had had lumbar radiographies, $80 \%$ had undergone a computed tomography scan and $64 \%$ had undergone magnetic resonance imaging. The most commonly prescribed medications were anti-inflammatories and first- or second-line analgesics. Thirty percent had already received morphine analgesics and $50 \%$ had taken antidepressants. Thirty-two percent had undergone lumbar surgery. Physiotherapy was frequently reported and, indeed, $6 \%$ of patients had participated in over 100 sessions. Total sick leave averaged 8.25 months over the study's follow-up period. Conclusion. - The time interval before referral to a multidisciplinary care team is long and so GPs should be encouraged and helped to organize this process earlier. It is also essential to determine factors which predict progression to chronic LBP.
\end{abstract}

(C) 2008 Published by Elsevier Masson SAS.

\section{Résumé}

Objectif. - La lombalgie chronique est un important problème socioéconomique, du fait des multiples actes médicaux et paramédicaux, et des nombreux arrêts de travail qu'elle engendre. Le but de cette étude est de décrire la prise en charge en soins primaires de lombalgiques chroniques, avant leur traitement dans un réseau multidisciplinaire de réadaptation à l'effort.

\footnotetext{
* Corresponding author.

E-mail address: isabelle.richard@univ-angers.fr (I. Richard).
} 
Méthodes. - Étude descriptive et rétrospective, réalisée par questionnaire auprès des généralistes de 72 patients traités dans le réseau régional. Résultats. - Les patients étaient suivis pour lombalgie depuis en moyenne quatre ans par leur généraliste, avec une fréquence de huit consultations spécifiques par an par patient. Quatre-vingt-treize pour cent des patients avaient vu un rhumatologue et $60 \%$ un chirurgien. Quatre-vingt-dix-huit pour cent des patients ont bénéficié de radiographies lombaires, $80 \%$ d'un scanner et $64 \%$ d'une IRM. Les traitements médicamenteux comportaient préférentiellement des antalgiques de palier 1 ou 2 et des anti-inflammatoires stéroïdiens ou non. Trente pour cent avaient déjà reçu des morphiniques et $50 \%$ des antidépresseurs. Un antécédent de chirurgie lombaire était retrouvé chez un tiers des patients. La kinésithérapie était fréquemment prescrite, avec $6 \%$ des patients ayant eu plus de 100 séances. La durée d'arrêt de travail était en moyenne de 8,25 mois.

Conclusions. - L'orientation vers un réseau spécialisé est tardive, il paraît important d'aider les généralistes à organiser un recours multidisciplinaire plus précoce pour les lombalgiques chroniques. La recherche des facteurs permettant de prédire, dès la phase précoce de la lombalgie, les patients à risque de chronicisation est également indispensable.

(C) 2008 Published by Elsevier Masson SAS.

Keywords: Chronic lower back pain; Primary care; Patient care management; Functional restoration

Mots clés : Lombalgie chronique ; Parcours de soins ; Soins primaires ; Réseau ; Réadaptation à l'effort

\section{English version}

\subsection{Introduction}

Nonspecific, chronic low back pain (LBP) is defined as more than three months of continuous pain in the lumbar region and without "red flags", that is to say in the absence of signs of fracture, inflammation, infection or tumours [21]. This pathology is a major socioeconomic issue, since $70 \%$ of the working population suffer or have already suffered from back pain [17]. Five to ten percent of cases of acute LBP will become chronic cases [5], which represent 70 to $90 \%$ of the costs $[15,25,31,33]$. A French study has evaluated the cost of LBP at $€ 15,000$ per patient [20] when both direct care provision (general \& specialist practice, additional investigations, physiotherapy, etc.) and indirect costs (notably sick leave payments) are taken into account.

The general practitioner (GP) is the front-line health professional for LBP patients. In France, LBP is the ninth most frequent pathology in general practice and accounts for $4.18 \%$ of a GP's activity [37]. In general practice, LBP management includes all health-oriented interventions (additional investigations, appointments with the GP or referrals to a specialist, treatments, etc.) which are prescribed, organized and coordinated by the physician with the patient's agreement. The physician relies on both national and international guidelines and his/her own experience when choosing the best care management option(s) for the LBP patient.

Current recommendations for LBP care insist on prescription of first- and second-line analgesics, which may potentially be combined with nonsteroidal anti-inflammatory drugs, muscle relaxants, tricyclic antidepressants and/or spinal glucocorticoid injections as second-line options [2,6,34]. Additional investigations and referrals to surgeons must be prescribed only if there is doubt as to the specific origin of the LBP or if surgery is clearly indicated. Physical exercise and muscle reconditioning are recommended [1,2].

As time goes by, the management of a patient who continues to suffer from chronic LBP (and, indeed, faces disability) becomes increasingly difficult and tends to follow the recommendations to a far lesser extent [22,42]. Despite a number of treatments and investigations, patients often do not achieve complete relief. This process leads to a therapeutic dead-end, with prolonged sick leave and professional disability for the patient. The multimodal origins of LBP (physical deconditioning, depression, social isolation, workplace conflicts, etc.) are often not taken into account and may account (at least in part) for these therapeutic failures [26,27]. Even when GPs do take into account these factors, they encounter difficulties in prescribing adequate physiotherapy, providing psychological support and organizing professional adjustment.

France's healthcare legislation has recently promoted "care networks". This type of organisational structure is well suited to the management of complex pathologies and the provision of long-term follow-up. Care networks are intended to allow the collective, regional-level action of professionals in response to a health problem [3]. These networks structure the multidisciplinary, overall management of the patient in the community, with the goal of providing coordination, prevention and education. They include the implementation of shared resources, continuous professional education, research activities and quality assessment procedures.

Within such networks, multidisciplinary programmes for LBP have been developed and evaluated [10,11,19,29,30,41]. These programmes include functional restoration modules based on physical exercise, psychological follow-up and professional rehabilitation. One such network exists in our part of France. The patient is referred to a multidisciplinary clinic where he/she undergoes a complete evaluation completed by a physical medicine and rehabilitation (PM\&R) specialist, an occupational physician and a psychologist. He/she is then referred to either a physiotherapist within the network or an outpatient program in a rehabilitation centre [24,32].

Several studies have described GPs' prescriptions for acute LBP and the difficulties that they have in sticking to the guidelines [42]; in France in particular, a prescription of bed rest is made in 28 to $35 \%$ of cases (for an average period of 4.4 days) $[18,35]$. These studies also revealed unduly long periods of sick leave and the weak compliance of Canadian and French GPs with the absence of indications for immediate radiological examinations and certain treatments (massage, etc.) 
$[9,18]$. Furthermore, data on specific aspects of the management of chronic LBP patients (the prescription of additional investigations, for example) show that there is a major discrepancy (at least in France) between the guidelines on one hand and actual practice in the prescription of computed tomography (CT) and magnetic resonance imaging (MRI) on the other [22]. The overall management of chronic LBP has only been described over short follow-up periods and has revealed the occurrence of frequent referral to specialists, a multitude of possible care tracks for these patients and the need to find out which practices are effective [40]. A recent study of French GPs' apprehensions and beliefs has confirmed the negative effect of these attitudes on the application of recommendations concerning physical activity and an early return to work [12]. Lastly, a number of studies have sought to evaluate the costs linked to this pathology $[8,20]$. To the best of our knowledge, the question of why and when GPs decide to refer a patient to a multidisciplinary rehabilitation care (when management becomes difficult, when their relationship with the patient becomes difficult or the occurrence of red flags, for example) has not yet been addressed, despite the importance of these matters in improving the use of the available facilities in general and rehabilitation centres in particular. Indeed, most studies show that prolonged sick leave and late referral to rehabilitation programmes result in a poor functional and professional prognosis. [39]. Patients should be assessed early - ideally at the time of first referral to a GP or at least within two months of LBP onset (i.e. during the subacute phase), in order to avoid progression to chronicity. Indeed, severity scores have been developed to help physicians rapidly identify patients at a high risk of chronic progression [38]. In contrast, referring all LBP patients at a very early stage to rehabilitation programmes is not possible, given the prevalence of LBP and the limited availability of rehabilitation facilities. There is also little evidence to suggest that systematic referral would be more efficient than good, global follow-up by a GP. Hence, the aim of the present study was to describe the content and timing of primary care management prior to referral of LBP patients to a multidisciplinary network.

\subsection{Patients and methods}

This was a retrospective survey of patients treated in a multidisciplinary care network in France. The inclusion criteria were as follows:

- chronic, nonspecific LBP;

- referral to the multidisciplinary clinic in 2006 (either directly by their GP or after a first appointment with a PM\&R specialist);

- included in the care network's functional restoration programme in the $P M \& R$ centre or in private physiotherapy.

Patients not treated in the network and those referred by another specialist (by an occupational physician, in particular) were excluded from the study.
Part of the information for each patient was collected from his/her medical records: gender, age, time since onset of symptoms, cumulative duration of sick leave, any history of depression, referral to a specialist, radiological investigations, standard lumbar X-ray, CT and/or MR imaging, treatments (medications, surgery, lumbar corsets or belts, etc.).

The referring GPs were contacted and invited to participate in a survey of the following items: the duration of follow-up for the LBP patient, the patient management (referral to a specialist, radiological investigations, etc.), prescribed treatments (oral medications, spinal glucocorticoid injections, physiotherapy, osteopathy, manipulation, acupuncture and other alternative medicines). Osteopathy and vertebral manipulation were considered as a single item, since neither the patients nor the GPs drew a clear distinction between the two techniques. The GPs were questioned about their contacts with occupational physicians and medical advisors within the social security system. Two semi-directed questions dealt with justification of radiological investigations and the provision of sick notes, if the latter had been mentioned. Multiple answers were accepted for each given patient. The survey was primarily performed by telephone. When the latter was not possible, the questionnaire was sent by post or completed during a face-to-face interview at the GP's surgery.

\subsection{Results}

In 2006, 134 patients had been treated in the rehabilitation care network. Of these, 47 had been referred by their GP and 25 had been referred by a PM\&R practitioner. Hence, 72 patients were included in the present study (Fig. 1). For 60 patients, we performed a telephone interview with the referring GPs. A further two GPs answered during a face-to-face interview in their surgery (four patients), whereas seven answered a postal questionnaire (out of eight sent). For 55 patients, all data were available. In 14 cases, some data were missing. Two questionnaires were very incomplete and one could not be recovered (for this patient, we only had information from the multidisciplinary clinic's file).

The study population had a mean age of $41 \pm 8$ years and $56 \%$ were female. Thirty-six percent had a history of depression and $50 \%$ were already on sick leave at the start of their treatment. After consultation in the multidisciplinary clinic, $60 \%$ of the patients received active, individual therapy from private physiotherapists and the others participated in a functional restoration programme in a rehabilitation centre.

The average time interval between the first appointment with the GP and consultation in the multidisciplinary clinic was $49 \pm 51$ months (range: four to 25 months). The patients estimated the time since onset of their LBP at $85 \pm 86$ months. During the follow-up period, patients had consulted their physician for LBP an average of $17 \pm 13$ times (range: 0 to 56), which means $8 \pm 7$ appointments per year per patient. The highest frequency observed was 32 appointments per year for one patient. 


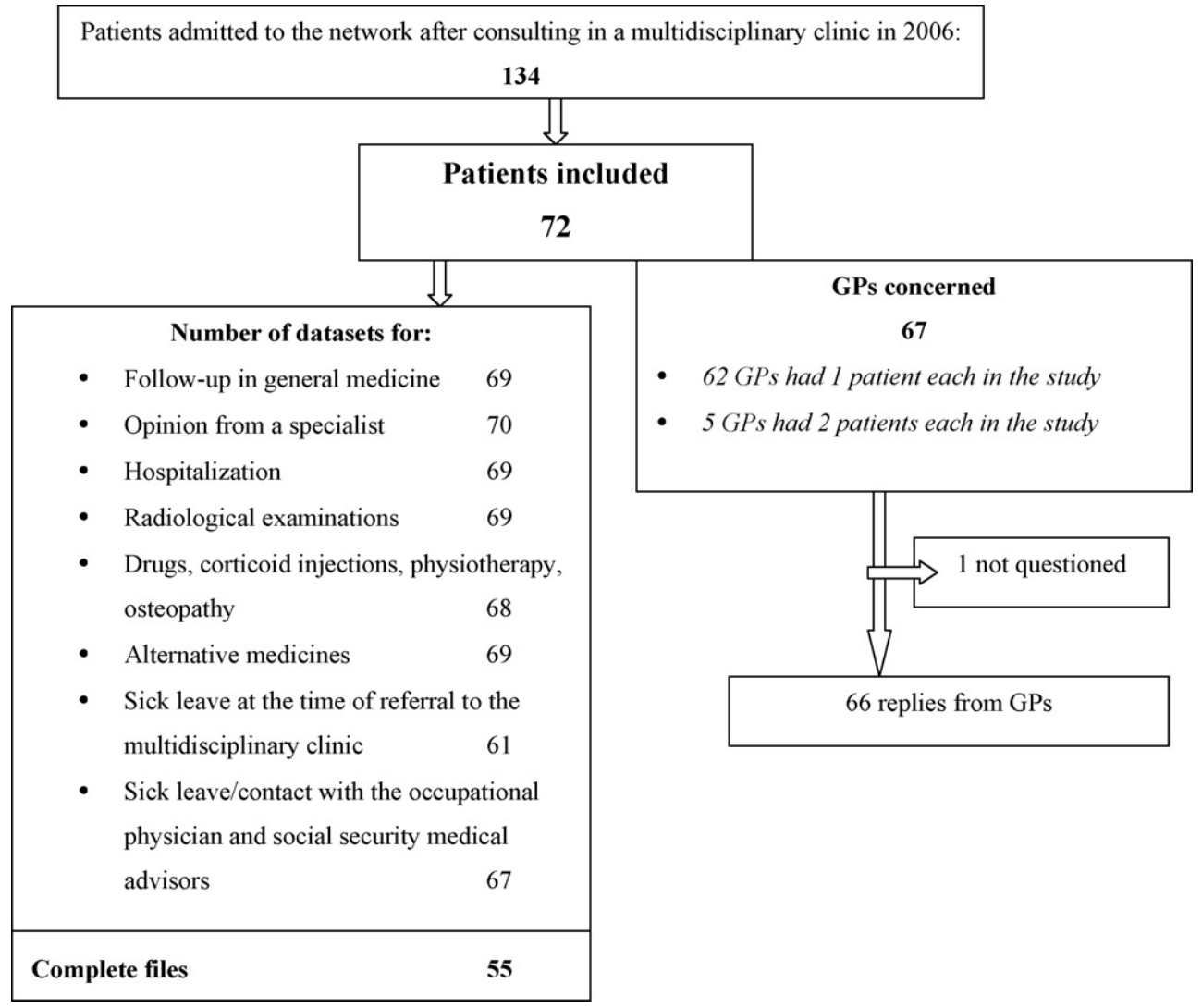

Fig. 1. Flow diagram.

Table 1

Referral to specialists and hospitalizations.

\begin{tabular}{lll}
\hline Specialist & Number of patients & Percentage of patients $(\%)$ \\
\hline Rheumatologist & 66 & 93 \\
Surgeon & 43 & 60 \\
$\quad$ Orthopaedic surgeon & 28 & 39 \\
$\quad$ Neurosurgeon & 20 & 28.5 \\
Pain clinic & 6 & 8.5 \\
Neurologist & 3 & 4.5 \\
Hospitalization & 13 & 19 \\
\hline
\end{tabular}

Patients were frequently referred to rheumatologists and surgeons, whereas hospitalizations and referrals to other specialists were reported more rarely (Table 1).

Almost all patients had received a standard radiographic examination (Table 2). Nearly $17 \%$ of the patients had undergone more than one CT scan. In response to the question "why did you prescribe CT or MRI?", 86\% of the GPs said that it was because of a clinical abnormality (i.e. a red flag), such as the existence of radiculalgia or the persistence of pain despite correctly implemented treatment. In six cases, the GP reported that the patient had insisted on having these examinations. In six other cases, the examinations had been prescribed by another physician. In some cases, the prescription was made because the physician was worried about the potential presence of a serious disease or in view of a history of surgery or a legal issue related to an occupational accident.
Seventy-five percent of the patients were being treated with first- or second-line analgesics at the time of the multidisciplinary clinic consultation (Table 3). Antidepressants were reported by half of the GPs but only by $25 \%$ of the patients. The other reported treatments are listed in Table 4 . Prior to management in the care network, most of the patients $(92,5 \%)$ had already received physiotherapy. The content of these sessions (active or passive physiotherapy, balneotherapy, etc.) could not be exactly determined. Only 10 patients (14\%) used alternative medicine (not including osteopathy), with five of these receiving mesotherapy. In only one of these cases was the GP skilled in this field. The other techniques reported were acupuncture (two patients), sophrology,

Table 2

Diagnostic investigations.

\begin{tabular}{lcl}
\hline Investigations performed & Number of patients & Percentage of patients $(\%)$ \\
\hline Radiography & 68 & 98.5 \\
CT (at least 1) & 55 & 80 \\
CT (2 or more) & 12 & 17.5 \\
MRI (at least 1) & 44 & 64 \\
MRI (2 or more) & 4 & 6 \\
CT and MRI & 35 & 51 \\
Myelography & 7 & 10 \\
Osteodensitometry & 1 & 1.5 \\
Electromyogram (legs) & 11 & 16 \\
Scintigraphy & 4 & 6
\end{tabular}


Table 3

Prescribed medications.

\begin{tabular}{|c|c|c|c|c|}
\hline \multirow[t]{2}{*}{ Prescribed medications } & \multicolumn{2}{|c|}{ In the GP's file $n=68$} & \multicolumn{2}{|c|}{ In the file $n=72$} \\
\hline & Number of patients & Percentage of patients & Number of patients & Percentage of patients $(\%)$ \\
\hline $\begin{array}{l}\text { 1st- or } 2 \text { nd -line analgesics combined } \\
\text { with NSAIDs } \pm \text { muscle relaxants }\end{array}$ & 68 & $100 \%$ & 71 & 98.5 \\
\hline 3rd -line analgesics & 20 & $29 \%$ & 9 & 12.5 \\
\hline Antidepressants & 31 & $46 \%$ & 18 & 25 \\
\hline Steroids & MD & MD & 7 & 14 \\
\hline $\begin{array}{l}\text { On analgesics at the time of consultation } \\
\text { in the multidisciplinary clinic }(n=70)\end{array}$ & MD & $\mathrm{MD}$ & 51 & 73 \\
\hline
\end{tabular}

$\mathrm{MD}=$ missing data.

Table 4

Other treatments.

\begin{tabular}{lll}
\hline Other treatments used & $\begin{array}{l}\text { Number of } \\
\text { patients }\end{array}$ & $\begin{array}{l}\text { Percentage of } \\
\text { patients (\%) }\end{array}$ \\
\hline Lumbar surgery & 23 & 32 \\
Glucocorticoid injections & 35 & 52 \\
Lumbar corsets or belts & 53 & 74 \\
Physiotherapy (Total) & 63 & 93 \\
1 to 30 sessions & 21 & 31 \\
30 to 100 sessions & 38 & 56 \\
More than 100 sessions & 4 & 6 \\
Alternative medicine & 31 & 43 \\
Osteopathy, manipulation & 25 & 37 \\
Other types of alternative medicines & 10 & 14 \\
\hline
\end{tabular}

hypnosis, electrotherapy and referral to traditional therapists (magnetization, etc.).

Eighty-six percent of the patients had been on sick leave at least once. The mean, cumulative duration of these episodes of sick leaves was $8.25 \pm 9.25$ months (range: 0 to 43). According to the GP, $82 \%$ of the episodes of sick leave were justified in view of a demanding occupation which was incompatible with pain. The other reported answers to this semi-structured question were as follows: sick leave due to another condition (four cases); psychological difficulties due to work that was incompatible with LBP (three cases); initial prescription by another doctor (one case); sick leave following an occupational accident (one case). The origin of the LBP was stated as being an occupational accident in $25 \%$ of cases ( 15 out of 62 patients; missing data for 10 patients). For patients who had received follow-up by an occupational physician, the GP contacted the latter in $36.5 \%$ of the cases. Contact with a medical advisor from the social security department was reported in $26 \%$ of the cases.

\subsection{Discussion}

This study reveals the prolonged management of chronic LBP patients by their GPs, with many specialist referrals, investigations and treatments. Our results also show that most patients have consulted their family doctor very frequently. The mean duration of follow-up (from the first appointment for LBP with their GP to consultation in a multidisciplinary clinic) is four years. This long period can (at least in part) be explained by the recent creation of this type of care network. The times since LBP onset stated by the GPs and by the patients themselves differ greatly (almost twice as long, according to the patient). Patients do not necessarily see their GP as soon as LBP begins; furthermore, in the French system, the patients may have seen two GPs successively. This time since onset of LBP is in agreement with previous French results, which found that $46.7 \%$ of cases lasted for more than five years [8].

The number of appointments with the GP was very high for some patients. This observation can be explained by the length of the follow-up and by the GP's central role as a prescriber - a role that was further reinforced by a recent reform of the French public healthcare system, which compels patients to see their GP before consulting a specialist. The necessity to prescribe periods of sick leave that are as short as possible (but then potentially extend the latter) may explain the high number of appointments per patient. Yet, this number of appointments is probably an underestimate, since LBP may be discussed during an appointment for another health problem. Furthermore, GPs sometimes see patients at their home in the event of acute recurrence of back pain, and these visits are probably not always recorded. The relationship of trust between a physician and his patient can suffer as a result of these frequent appointments. A context of chronic LBP is uncomfortable for both the disabled patient and the physician, and the latter is obliged to prescribe sick leave and analgesics for a very long time.

In almost all cases, the management includes referral to a rheumatologist. In a Dutch study on the management of LBP over a one-year period, $1.5 \%$ of the patients had seen a rheumatologist and 14\% had consulted a surgeon [40]. Referrals to a specialist are more frequent in cases of radiculalgia [42].

In terms of additional examinations, MRI or CT (or indeed both) are very frequently prescribed and often repeated. A French study showed that (i) $75 \%$ of the prescriptions of CT for LBP did not comply with the guidelines and (ii) $70 \%$ did not induce any change in the treatment [22]. Another French study showed that many other investigations (such as radiculography) are prescribed (and often in combination with MRI and CT), despite the lack of an indication for surgery [20]. A North American study also reported that a high proportion of such investigations were prescribed during the acute pain phase, which again is at variance with current guidelines [42]. 
Although physicians justify prescription of these investigations by the persistence of pain, the pressure exerted by patients can also be a factor. Patients tend to trust radiological investigations more than their physician's clinical opinion [7].

Regarding medications, morphine analgesics are often prescribed. Steroids were regularly reported (14\%), although there is no evidence of their effect in either LBP or sciatica [34]. One quarter of the patients were not taking analgesics at the time of consultation at the multidisciplinary clinic, despite the fact that their LBP was disabling enough to raise the question of multidisciplinary rehabilitation in the first place. This could be explained by several factors: poor drug tolerance, insufficient efficacy or the absence of or a decrease in pain during periods of sick leave. The high rate of antidepressant prescription can be explained by (i) the history of depression in the study population and (ii) depression related to the social and occupational consequences of LBP. Tricyclics address both pain and depression and can be of value as second-line treatments. In the study by Haumesser et al., $32 \%$ of the patients had already taken antidepressants [20]. Our results show a discrepancy between the rates of prescription of antidepressants reported by the patients and the GPs, respectively. This raises the question of whether the patient does not actually know what kind of medications he/she is taking or whether he/she (either deliberately or unconsciously) omits to mention these medications.

Thirty-two percent of the patients had undergone surgery. The studies by Bazin et al. [8] and Haumesser et al. [20] reported values of 18 and $87 \%$, respectively. These discrepancies confirm that the management of LBP varies according to the health-care systems and a given study's inclusion criteria. Half of our patients received had glucocorticoid injections as a second-line treatment [2]. Physiotherapy was very frequently prescribed and some patients had received more than 100 sessions. This result confirms the major role of physiotherapy in the management of LBP but does not tell us whether these prescriptions are due to the guidelines, the physician's habits or the patient's requests. It would be interesting to gain information on the content of these sessions (massage, active functional restoration, etc.) and the reasons for extending the treatment to over 100 sessions (probably in the absence of improvement). Haumesser et al. and Bazin et al. respectively reported a physiotherapy prescription rate of 78 and $93 \%$ and a glucocorticoid injection rate of 33 and 54\% [8,20].

The use of "alternative" medicines is probably underestimated, since this study questioned GPs who are not necessarily informed of this kind of treatment by their patients. A FrancoCanadian study considered that $50 \%$ of alternative medicine users do not inform their GP and that $39 \%$ of chronic LBP patients use alternative medicines [14,28].

The average total duration of sick leave prior to referral to the care network was $8.25 \pm 9.25$ months. This is a problem, since it is acknowledged that the chances of recovery and a return to work after one year of LBP are very low [4,23,39]. The coordination between the GP and the occupational physician is important, in order to facilitate work-place adaptation and the return to work. Our data show that contact between the occupational physician and the family doctor occurs in $36 \%$ of cases. This figure is low, given the long duration of sick leave. It would be interesting to establish the reasons for this absence of communication: lack of time, difficulties in making contact, reticence from the patients...? Improving this coordination is still essential and may be a simple, attainable objective in primary care. The French public health code specifies that patients should visit their occupational physician prior to returning to work, and this opportunity for $\mathrm{GP}$-occupational physician dialogue could be more widely used.

One of the limitations of this study relates to selection of the population through attendance at a multidisciplinary clinic. Hence, these patients are not representative of the overall LBP population. The individuals studied here were already facing major difficulties at work and had been referred to the network with a view to active rehabilitation and keeping their job. There was also some selection bias for the studied GPs because the latter had already sent at least one patient to the care network.

At present, multidisciplinary patient management and functional restoration are mainly available in hospital-based facilities or within care networks. These facilities are only available to a limited number of patients. It is therefore necessary to better define the criteria for referral to these facilities and to spread this kind of management to the primary care providers themselves.

Further studies are needed to evaluate possible improvements in the management of LBP patients. Indicators of biopsychosocial complexity are required to help refine this process of referral to specific health-care facilities. These indicators might include the duration of sick leave, the repetition of additional examinations and referrals to a specialist, prescription of more than 30 sessions of physiotherapy. A Swiss study showed that a combination of a medical complexity score and the duration of sick leave best predicted the outcome. [36]. It would also be interesting to better understand (i) how a GP investigates an LBP patient's psychosocioprofessional environment and (ii) which psychobehavioural strategies are used by patients to face these difficulties [16].

Although improving current practice does not systematically require a care network, the coordination between the various stakeholders (GPs, occupational physicians, specialists and physiotherapists) is crucial in order to provide coherent management, comply with the guidelines and achieve a return to work for the patient. Indicators such as contacts between GPs and occupational physicians or physiotherapeutic assessments could help measure the impact of continuing medical education on this subject. Upstream of this chronic LBP management, further studies are necessary to determine predictive criteria and scores which could be used for early prediction of progression to chronicity [38].

\subsection{Conclusion}

The management of LBP patients includes many medical and paramedical interventions and prolonged periods of sick leave. It takes a long time for these patients to be referred to a 
multidisciplinary rehabilitation network, whereas the chances of returning to work correlated with the early resumption of physical activity. General practitioners need to become more familiar with multidisciplinary management and must develop criteria for early referral of patients who genuinely require specific interventions. Psychosocial risk factors for the progression to chronicity also deserve further investigation.

\section{Version francaise}

\subsection{Introduction}

La lombalgie commune se définit comme une douleur de la région lombaire ne présentant pas de signes évocateurs d'une pathologie inflammatoire, infectieuse, fracturaire ou tumorale ; elle est dite chronique après trois mois d'évolution consécutive [21]. Cette pathologie pose un important problème de santé publique. En effet, $70 \%$ de la population en âge de travailler souffre ou a déjà souffert du dos [17]. Cinq à dix pour cent des lombalgies aiguës vont devenir chroniques [5] et ces patients chroniques représentent 70 à $90 \%$ des coûts liés à la lombalgie $[15,25,31,33]$. Une étude française à évalué ces coûts à 15000 euros par patients [20]. Ces coûts sont dus, d'une part, à la prise en charge directe (consommation de soins, examens complémentaires, séances de kinésithérapie...) et, d'autre part, aux indemnités journalières des arrêts de travail (coût indirect), qui en font une priorité socioéconomique.

Le médecin généraliste est le premier acteur de soin devant une lombalgie. Cette pathologie est le neuvième motif de consultation en médecine générale, avec 4,18\% des actes réalisés [37]. Dans le cadre de la médecine générale, le parcours de soin est l'ensemble des moyens de santé (examens complémentaires, consultations chez le généraliste ou le spécialiste, traitements) que le médecin prescrit, organise et centralise autour du patient et en accord avec celui-ci. Le médecin s'appuie sur les recommandations nationales ou internationales et sur son expérience personnelle, pour aiguiller au mieux le cheminement du patient dans cette prise en charge.

Les recommandations actuelles de prise en charge de la douleur des lombalgiques chroniques insistent sur un traitement antalgique de palier I ou II, éventuellement associé à des antiinflammatoires non stérö̈diens, des myorelaxants, des antidépresseurs tricycliques et des infiltrations en seconde intention $[2,6,34]$. Les examens complémentaires et les avis spécialisés ne sont à prescrire qu'en cas de doute sur une pathologie plus grave ou si un acte chirurgical est envisagé. En revanche, l'exercice physique et parfois le reconditionnement à l'effort sont désormais recommandés [1,2]. Devant des douleurs invalidantes se prolongeant dans le temps, le parcours de soins des patients lombalgiques s'alourdit au fur et à mesure du suivi et s'éloigne plus ou moins de ces recommandations [22,42], en n'apportant souvent qu'une réponse incomplète à leurs attentes de soulagement. Le médecin et son patient peuvent alors se trouver dans une situation d'impasse thérapeutique, aboutissant à la prolongation des arrêts de travail et parfois à la mise en invalidité. Ces échecs s'expliquent en partie par l'absence de prise en charge du caractère multifactoriel de la lombalgie chronique : déconditionnement à l'effort [26,27], répercussions psychologiques de type dépressif, isolement social, et difficultés professionnelles. Les médecins généralistes prennent en charge cette multidisciplinarité mais rencontrent des difficultés notamment : dans le soutien psychologique, l'adaptation professionnelle et la prise en charge en rééducation, très variable en fonction du kinésithérapeute libéral (massages, balnéothérapie, renforcement musculaire...).

L'organisation des soins sous forme de réseau est récente en France et particulièrement adaptée à des pathologies complexes et des suivis au long cours. Cette organisation est créé par l'article L. 6321-1 du Code de santé publique. L'HAS définit le réseau de santé comme une action collective apportée par des professionnels en réponse à un besoin de santé de la population, à un moment donné sur un territoire donné [3]. Ces réseaux permettent une prise en charge multidisciplinaire et globale du patient dans son environnement socioprofessionnel et familial, de plus ils ont des objectifs de coordination des soins, de prévention, d'éducation, de mutualisation des ressources, de formation professionnelle et de recherche, ainsi que des obligations d'évaluation (décret du 17/12/2002).

Des programmes de prise en charge multidisciplinaire des lombalgiques, profitant d'une telle organisation en réseau, ont été développés et évalués de façon positive $[10,11,19,29,30,41]$ : ceux-ci comprennent une restauration fonctionnelle par de l'exercice physique, ainsi qu'un accompagnement psychologique, et surtout une aide à la réinsertion professionnelle. Ainsi, après une première consultation multidisciplinaire, où le patient est évalué par un médecin rééducateur, un médecin du travail et un psychologue, le réseau régional propose une réadaptation à l'effort, auprès de kinésithérapeutes libéraux du réseau ou au sein même d'un service de réadaptation fonctionnelle [24,32].

Plusieurs études ont décrit les prescriptions des médecins généralistes devant une lombalgie aiguë : montrant des difficultés dans l'application des recommandations [42], avec notamment en France une prescription de repos au lit dans 28 à $35 \%$ des cas et ce pour 4,4 jours en moyenne [18,35], des arrêts de travail trop longs et une faible compliance des médecins généralistes canadiens et français aux recommandations sur l'inutilité de l'imagerie précoce et de certains traitements (massages. . ) [9,18]. D'autres ont décrit une seule partie de la prise en charge de la lombalgie chronique : par exemple pour l'imagerie il semble persister en France un décalage entre les règles de bonne pratique et la réalité des indications et des prescriptions de tomodensitométrie (TDM) et d'imagerie par résonance magnétique (IRM) [22]. La description de la prise en charge complète des lombalgiques chroniques sur une période de quelques mois uniquement a montré une multitude de parcours de soins possibles et la nécessité de mieux évaluer les pratiques efficaces [40]. Une étude récente a exploré les peurs et les croyances des médecins généralistes français, mettant en évidence leur influence négative sur l'application par ces médecins des recommandations concernant l'activité physique et la reprise du travail précoce [12]. Certaines études enfin ont eu pour objectif d'évaluer les coûts liés à la pathologie $[8,20]$. Aucune étude n'a pour l'instant cherché à déterminer, pour 
quelles raisons et à quel moment du suivi les médecins généralistes estiment nécessaire un recours à une prise en charge réadaptative multidisciplinaire : une impasse de la prise en charge déjà avérée, un épuisement de leur relation avec le patient, ou des signes de gravité... Cet élément est pourtant déterminant pour optimiser l'utilisation des moyens disponibles en particulier dans les services de médecine physique et réadaptation ; il existe en effet de nombreux arguments pour penser qu'une orientation trop tardive, après un temps d'arrêt de travail très long n'est pas optimale. Plus la durée de la douleur et de l'arrêt de travail se prolongent plus les chances de guérison sont faibles [39]. Les patients doivent être évalués au plus tôt, idéalement dès les premières consultations, ou au pire avant la huitième semaine d'évolution, pendant la phase subaiguë, pour éviter la chronicisation, certains proposent des critères de gravité facilitant cette orientation précoce des patients à risque [38]. À l'inverse une orientation très précoce n'est pas envisageable compte tenu de la fréquence de cette pathologie et du nombre de places disponibles dans des programmes intensifs et il y a peu d'arguments pour assurer qu'elle serait plus efficace qu'une prise en charge en soins primaire bien conduite. L'objectif de cette étude est de décrire le parcours de soins des patients lombalgiques chroniques, en termes de durée et de contenu, avant leur inclusion dans un réseau de réadaptation à l'effort.

\subsection{Patients et méthodes}

Il s'agit d'une enquête rétrospective, réalisée auprès des médecins généralistes des patients traités par le réseau. Les critères d'inclusion ont été les patients :

- présentant une lombalgie chronique commune ;

- vus en consultation multidisciplinaire en 2006 ;

- inclus dans le programme de réadaptation à l'effort institutionnel ou libéral du réseau et ;

- adressés à cette consultation multidisciplinaire par leur médecin généraliste directement ou via une consultation avec l'un des médecins de Médecine physique et réadaptation (MPR) du réseau.

\section{Ont été exclus :}

- les patients non traités par le réseau ;

- les patients adressés par un autre spécialiste, notamment par leur médecin du travail.

Pour chaque patient, une partie des informations a été recueillie directement dans le dossier de la consultation multidisciplinaire : sexe, âge, durée des symptômes, durée cumulée des arrêts de travail, antécédents dépressifs, consultations auprès de spécialistes, examens d'imagerie (radiographies lombaires standards, TDM, IRM, radiculographies), et traitements entrepris (médicamenteux, chirurgicaux, corsets ou ceintures lombaires).

Les médecins généralistes concernés ont été contactés pour répondre à un questionnaire comportant : la durée de suivi du patient pour lombalgie, le nombre de consultations en médecine générale pour lombalgie pendant ce suivi, la prise en charge du patient (consultations auprès de spécialistes, examens d'imagerie), les différents traitements entrepris (médicaments, infiltrations, séances de kinésithérapie, ostéopathie ou manipulations, acupuncture et autres médecines alternatives). L'ostéopathie et les techniques manuelles sont considérées dans un même item, la différence étant difficile à affiner, même auprès des médecins. Les médecins généralistes ont été interrogés sur leurs contacts avec le médecin du travail du patient, ainsi qu'avec le médecin conseil de la Sécurité sociale. Deux questions semi-dirigées portaient sur la justification de l'imagerie et des arrêts de travail, dans le cas où ils avaient été prescrits, et plusieurs réponses étaient acceptées pour chaque patient. Les questions ont été posées de préférence par téléphone. En cas d'impossibilité, le questionnaire a été envoyé par courrier ou réalisé en face à face au cabinet à la demande du médecin. Les interviews ont eu lieu entre février et juillet 2007.

Le nombre de dossiers a été limité par le nombre de patients pris en charge par le réseau sur l'année étudiée et par la sélection de patients, dont le généraliste a pris lui-même l'initiative d'un traitement de réadaptation fonctionnelle. Les analyses statistiques ont été descriptives, avec évaluation des moyennes, écart-types, minimum, maximum et fréquences.

\subsection{Résultats}

En 2006, 134 patients ont été pris en charge en rééducation par le réseau. Dans ce groupe, 47 patients ont été adressés directement par leur médecin généraliste et 25 via un médecin de MPR, soit 72 patients inclus au total dans l'étude (Fig. 1).

Les questionnaires ont concerné 61 médecins généralistes du Maine et Loire et six de départements limitrophes. Pour 60 patients, le questionnaire téléphonique a pu être possible. Deux médecins ont répondu lors d'un entretien au cabinet (quatre patients), tandis que sept ont répondu à un questionnaire « papier» (sur le total des huit envoyés). Pour 55 patients, les informations ont pu être recueillies de façon complète, dans 14 cas il manquait quelques informations, deux questionnaires étaient très incomplets et un n'a pas pu être recueilli, pour ce dernier patient seules les données issues de la consultation multidisciplinaire ont donc été exploitées.

Les 72 patients inclus avaient en moyenne $41 \pm 8$ ans et on comptait $56 \%$ de femmes. Trente-six pour cent des patients présentaient un antécédent dépressif et $50 \%$ étaient en arrêt de travail au début de leur prise en charge dans le réseau. À l'issue de la consultation multidisciplinaire, $60 \%$ des patients ont bénéficié d'un programme de réadaptation auprès d'un kinésithérapeute libéral du réseau, les autres ont été traités en restauration fonctionnelle en centre de rééducation.

Les médecins généralistes ont déclaré suivre les patients pour lombalgie en moyenne depuis $49 \pm 51$ mois avant la prise en charge dans le réseau (minimum : quatre mois, maximum : 25 ans). Lors de la consultation multidisciplinaire, les patients ont estimé cette durée d'évolution à $85 \pm 86$ mois. Pendant le suivi, les patients ont consulté leur médecin généraliste pour lombalgie en moyenne $17 \pm 13$ fois ( $\min : 0, \max : 56$ fois), ce 
Patients pris en charge après la consultation multidisciplinaire

134

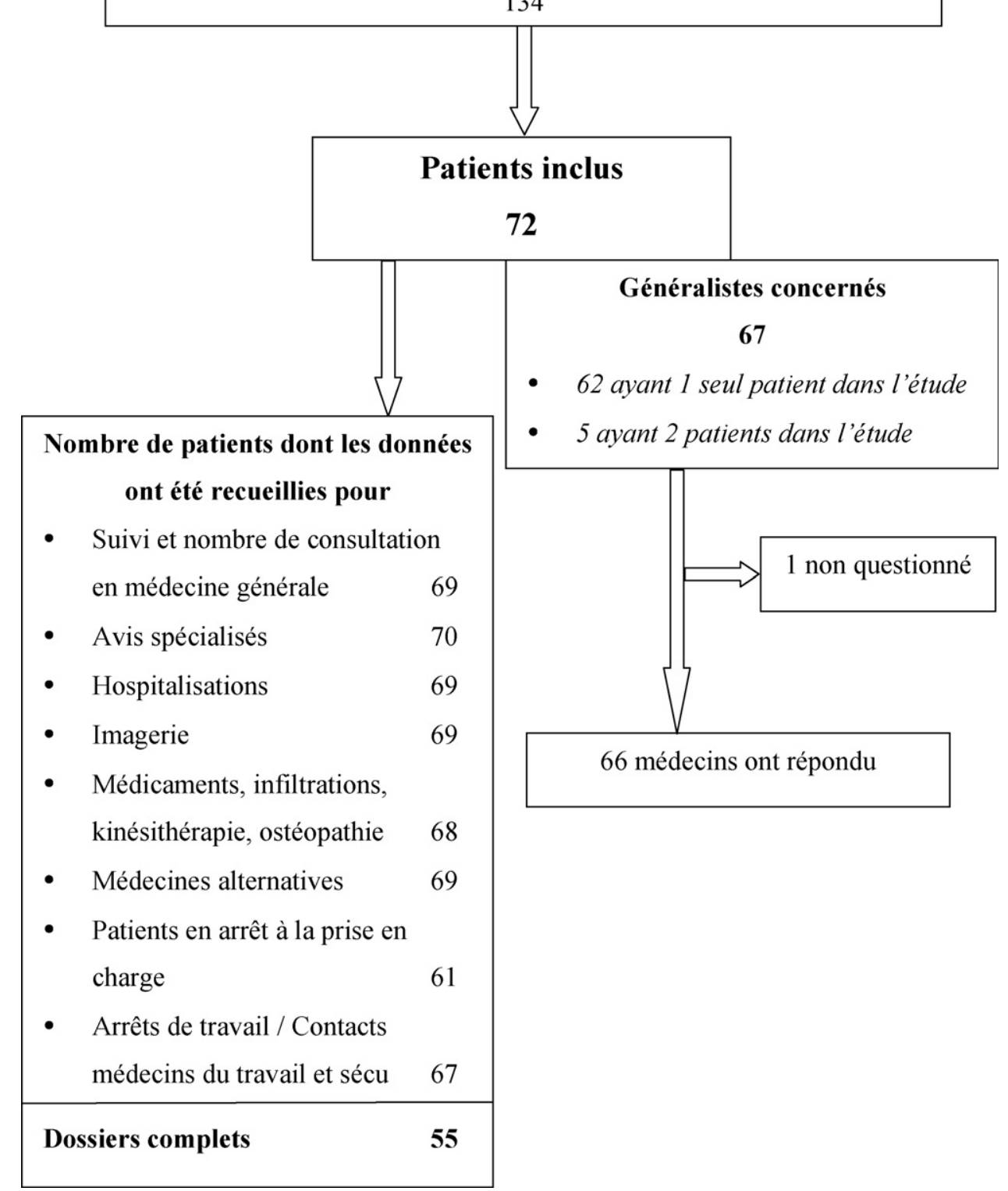

Fig. 1. Schéma de l'étude.

qui représente $8 \pm 7$ consultations par an par patient, cette fréquence allant pour un patient jusqu'à 32 consultations par an.

Le spécialiste consulté le plus fréquemment par les patients est le rhumatologue puis le chirurgien, tandis que les hospitalisations et les autres avis sont plus rares (Tableau 1).

Presque tous les patients ont bénéficié de radiographies standard (Tableau 2). Près d'un patient sur cinq a eu plusieurs scanners. À la question « pourquoi avoir prescrit une TDM ou une IRM ? », les médecins ont répondu à $86 \%$ que le motif de prescription était une anomalie clinique, de type radiculalgie, ou la persistance des douleurs, malgré un traitement bien conduit. Six fois, ils ont évoqué la pression des patients à avoir ces examens et dans six autres cas l'examen avait été prescrit par un autre médecin. De façon ponctuelle, la prescription était motivée par l'inquiétude du médecin pour une pathologie grave, un antécédent de chirurgie ou la dimension médicolégale d'un accident de travail.

Soixante-quinze pour cent des patients vus en consultation multidisciplinaire étaient sous traitement antalgique au moment de celle-ci (Tableau 3). On retrouve en interrogeant les médecins généralistes que la moitié des lombalgiques a été traitée par antidépresseurs à un moment donné de leur suivi, alors que seulement un quart des patients déclare avoir été traité par cette classe de médicament.

Les autres traitements proposés aux patients sont référencés dans le Tableau 4. Avant leur inclusion dans le réseau, la majorité des patients $(92,5 \%)$ ont déjà eu recours à la kinésithérapie. Le contenu de ces séances (kinésithérapie passive, active, balnéothérapie...) n'a pas pu être défini. 
Tableau 1

Spécialistes consultés et hospitalisations.

\begin{tabular}{lll}
\hline $\begin{array}{l}\text { Spécialiste consulté } \\
\text { (au moins une fois) }\end{array}$ & $\begin{array}{l}\text { Nombre de } \\
\text { patients }\end{array}$ & $\begin{array}{l}\text { Pourcentage de } \\
\text { patients }(\%)\end{array}$ \\
\hline Rhumatologue & 66 & 93 \\
Chirurgien & 43 & 60 \\
$\quad$ Orthopédiste & 28 & 39 \\
$\quad$ Neurochirurgien & 20 & 28,5 \\
Consultation douleur & 6 & 8,5 \\
Neurologue & 3 & 4,5 \\
Hospitalisation & 13 & 19 \\
\hline
\end{tabular}

Tableau 2

Examens complémentaires.

\begin{tabular}{lll}
\hline Examen réalisé & $\begin{array}{l}\text { Nombre de } \\
\text { patients }\end{array}$ & $\begin{array}{l}\text { Pourcentage de } \\
\text { patients }(\%)\end{array}$ \\
\hline Radiographies & 68 & 98,5 \\
TDM (au moins 1) & 55 & 80 \\
TDM (2 ou plus) & 12 & 17,5 \\
IRM (au moins 1) & 44 & 64 \\
IRM (2 ou plus) & 4 & 6 \\
TDM et IRM & 35 & 51 \\
Radiculographie & 7 & 10 \\
Ostéodensitométrie & 1 & 1,5 \\
Électromyogramme (membres inférieurs) & 11 & 16 \\
Scintigraphie & 4 & 6 \\
\hline
\end{tabular}

Un recours aux médecines alternatives (hors ostéopathie) a été déclaré seulement pour dix patients $(14 \%)$ avec, en particulier, cinq patients traités en mésothérapie ; dans un seul de ces cas le médecin traitant avait une compétence dans ce domaine. Les autres techniques citées sont l'acupuncture (deux patients), les pratiques de «magnétiseur » ou de « rebouteux », la sophrologie, l'hypnose, l'électrothérapie.

Quatre-vingt-six pour cent des patients ont eu un arrêt de travail. La durée cumulée d'arrêt est en moyenne de $8,25 \pm 9,25$ mois (min : 0, max : 43 mois). Dans $82 \%$ des cas, la prescription de l'arrêt était justifiée pour le médecin, par une charge physique liée au travail, incompatible avec la douleur du patient. Les autres réponses à cette question semiouverte étaient : arrêt nécessaire du fait d'une autre pathologie (quatre réponses) ; arrêt nécessaire au traitement (quatre réponses) ; demande insistante du patient (trois réponses) ; charge psychologique du travail incompatible avec la lombalgie (trois réponses); prescription initiale par un autre médecin (une réponse) ; nécessité dans le cadre d'un accident de travail (une réponse). La lombalgie était prise en charge au titre d'un accident de travail dans $25 \%$ des cas ( 15 patients sur 62 avec dix données manquantes pour cette information). Pour les patients ayant un médecin du travail, les médecins traitants n'ont eu un contact avec lui que dans 36,5\% des cas. Le contact avec le médecin conseil de la Sécurité sociale n'a lieu que dans $26 \%$ des cas.

\subsection{Discussion}

L'étude met en évidence une prise en charge longue de ces patients, avec de nombreux recours aux soins, notamment auprès de leurs «médecins de famille ». La durée de suivi, entre la première consultation auprès du généraliste pour lombalgie et le recours à la consultation multidisciplinaire est en moyenne de quatre ans et s'explique en partie par la création récente du réseau. Il existe une différence importante entre la durée de suivi déclarée par le médecin et la durée de la lombalgie déclarée par le patient lors de la consultation multidisciplinaire (deux fois plus longue en moyenne). Les patients ne consultent pas forcément dès les premières douleurs et peuvent avoir changé de médecin traitant. Cette durée de la lombalgie, malgré une organisation locale d'un système de soins, concorderait avec les résultats français de 1998, qui retrouvaient 46,7 \% de lombalgies évoluant depuis plus de cinq ans [8].

Le nombre de consultations en médecine générale est très important pour certains patients, ce qui s'explique par la longueur du suivi, et par la place du généraliste, en tant qu'acteur essentiel de prescription. Ce phénomène est renforcé par la récente réforme de la Sécurité sociale française, nécessitant le passage par le médecin traitant « référent » avant d'avoir recours à un spécialiste. La nécessité de prescrire des arrêts de travail les plus courts possibles explique un nombre important de consultations pour prolongations successives de ces arrêts. Pourtant, ce nombre de consultations en médecine générale est sans doute sous-estimé : la lombalgie chronique n'est pas forcément le motif principal amenant le patient à consulter et les visites à domicile, fréquentes lors des récurrences aiguës, ne sont probablement pas notées dans les dossiers des médecins au cabinet. Ce recours fréquent et prolongé peut engendrer un certain essoufflement de la relation entre le médecin généraliste et le patient. Cette situation

Tableau 3

Traitements médicamenteux.

\begin{tabular}{|c|c|c|c|c|}
\hline \multirow[t]{2}{*}{ Traitements médicamenteux reçus par le patient } & \multicolumn{2}{|c|}{ Dans le dossier des médecins généralistes $n=68$} & \multicolumn{2}{|l|}{ Dans le dossier $n=72$} \\
\hline & Nombre de patients & Pourcentage de patients & Nombre de patients & Pourcentage de patients (\%) \\
\hline $\begin{array}{l}\text { Antalgiques de paliers } 1 \text { ou } 2 \text { associés à des } \\
\text { anti-inflammatoires non stéroïdiens } \pm \text { myorelaxants }\end{array}$ & 68 & $100 \%$ & 71 & 98,5 \\
\hline Antalgiques de palier 3 & 20 & $29 \%$ & 9 & 12,5 \\
\hline Antidépresseurs & 31 & $46 \%$ & 18 & 25 \\
\hline Corticoïdes & NR & NR & 7 & 14 \\
\hline $\begin{array}{l}\text { Sous antalgiques le jour de la consultation } \\
\text { multidisciplinaire }(n=70)\end{array}$ & NR & NR & 51 & 73 \\
\hline
\end{tabular}

$\mathrm{NR}=$ non renseigné. 
Tableau 4

Autres traitements.

\begin{tabular}{lll}
\hline Autres traitements utilisés & $\begin{array}{l}\text { Nombre de } \\
\text { patients }\end{array}$ & $\begin{array}{l}\text { Pourcentage de } \\
\text { patients (\%) }\end{array}$ \\
\hline Chirurgie lombaire & 23 & 32 \\
Infiltrations & 35 & 52 \\
Corset ou ceinture lombaire & 53 & 74 \\
Kinésithérapie (Total) & 63 & 93 \\
1 à 30 séances & 21 & 31 \\
30 à 100 séances & 38 & 56 \\
Plus de 100 séances & 4 & 6 \\
Médecines « alternatives » & 31 & 43 \\
Ostéopathie, manipulations & 25 & 37 \\
Autres médecines alternatives & 10 & 14 \\
\hline
\end{tabular}

chronique n'est confortable ni pour le patient, souffrant de sa situation d'invalidité, ni pour le médecin, contraint à des prolongations d'arrêts de travail et des prescriptions d'antalgiques au long cours.

Pour ce qui est du parcours de soins, l'avis d'un spécialiste est demandé fréquemment, voire systématiquement pour l'avis rhumatologique. Dans une étude hollandaise, observant la prise en charge des lombalgiques chroniques sur un an seulement, on ne retrouvait que $1,5 \%$ de recours au rhumatologue, et $14 \%$ à un chirurgien [40]. Les avis spécialisés seraient beaucoup plus demandés en cas de radiculalgies [42].

Les examens de type IRM et TDM sont très fréquents, répétés et associés chez certains patients. Une étude française montre que $75 \%$ des TDM prescrits pour lombalgie ne respectent pas les recommandations et que $70 \%$ n'amènent aucune modification du traitement [22]. Une étude nordaméricaine retrouve également un fort taux de prescription d'examens dès la phase aiguë, malgré les recommandations [42]. Dans une étude réalisée en Moselle, beaucoup d'examens tels que radiculographies, association IRM plus TDM sont prescrits sans forcément aboutir à une indication chirurgicale [20]. Les examens sont justifiés par les médecins par la persistance des douleurs, mais la pression exercée par le patient apparaît aussi comme un facteur décisionnel : les patients font souvent plus confiance aux examens radiologiques qu'à l'examen clinique [7].

Concernant les traitements médicamenteux, la prescription de morphiniques est assez fréquente. Les corticoïdes sont prescrits régulièrement ( $14 \%)$, bien qu'ils n'aient fait la preuve de leur efficacité ni dans la lombalgie ni dans la lombosciatique [34]. On constate que, malgré une lombalgie chronique nécessitant une inclusion dans un réseau spécialisé, un quart de ces patients ne prend plus de traitement antalgique au moment de la consultation multidisciplinaire. Devant ce résultat, on peut émettre plusieurs hypothèses : une mauvaise tolérance médicamenteuse, un manque d'efficacité noté par le patient, une absence ou une diminution des douleurs pendant les arrêts de travail. Le fort taux de prescriptions d'antidépresseurs s'explique par l'importance des antécédents de dépression chez ces patients, ainsi que par les dépressions réactionnelles à la pathologie. La prescription de tricycliques permet de traiter le patient sur les deux plans antalgique et antidépresseur et fait partie des traitements qui peuvent être proposés en deuxième intention. Dans l'étude de Haumesser et al. en Moselle $32 \%$ des patients avaient reçu un antidépresseur [20]. Dans le dossier du réseau, seulement un quart des patients déclare une prescription d'antidépresseurs, contre la moitié de cas déclarés par leurs médecins. On peut alors se demander si le patient sait quelle classe thérapeutique lui est prescrite ou s'il omet, délibérément ou inconsciemment, de signaler ces traitements.

Les interventions chirurgicales sont retrouvées dans un tiers des cas. L'étude de Bazin et al. retrouvait $18 \%$ de chirurgie [8], contre $87 \%$ chez Haumesser et al. [20], ce qui confirme l'hétérogénéité des prises en charge en fonction des systèmes de soins régionaux et des critères d'inclusion des études. Les infiltrations réalisées chez la moitié des patients font partie du traitement recommandé en seconde intention [2]. Le recours à la kinésithérapie est très fréquent et certains patients ont bénéficié de plus de 100 séances. Ce résultat confirme la place importante de la rééducation dans le parcours de soin des lombalgiques, sans pour autant définir si ce recours est lié à une demande des patients, une conviction des médecins ou une prise en compte des recommandations. Il serait également intéressant de savoir quel type de rééducation a été réellement proposé (massages, renforcement musculaire...) et pourquoi elle est poursuivie jusqu'à 100 séances, alors qu'elle n'apporte probablement plus d'amélioration à ce stade. On retrouve chez Bazin et al. et Haumesser et al. respectivement 78 et $93 \%$ de prescriptions de kinésithérapie et 33 et $54 \%$ d'infiltrations $[8,20]$.

Les médecines dites «parallèles » sont, quant à elles, probablement sous-estimées, puisque l'étude a été réalisée auprès des généralistes, peu ou pas informés des recours de ce type par leurs patients : dans une étude franco-canadienne on considère que $50 \%$ des personnes utilisant ces médecines le font sans en avertir leur médecin traitant et que $39 \%$ des rachialgiques chroniques utilisent des médecines « alternatives » $[14,28]$.

La durée moyenne d'arrêt de travail est de plus de $8,25 \pm 9,25$ mois avant le traitement dans le réseau, ce qui est inquiétant, puisqu'il est désormais admis que les chances de guérison et de reprise du travail sont très faibles au-delà d'un an d'évolution $[4,23,39]$. Environ un quart des patients était pris en charge en accident de travail, ce résultat est important à prendre en compte étant donné que le type, la pénibilité et la satisfaction au travail est un facteur de risque important de chronicisation $[13,38]$. La coordination entre le médecin généraliste et le médecin du travail est indispensable pour favoriser la reprise du travail et une éventuelle adaptation de poste, mais il n'est retrouvé de contacts entre eux que dans $36,5 \%$ des cas : cette coordination est donc trop faible si on la confronte à la durée moyenne des arrêts de travail, d'autant plus que les médecins du travail ne sont pas systématiquement mis au courant des arrêts de travail par les patients. Il aurait été intéressant de préciser quelles sont les raisons de cette absence de coordination : le manque de temps et les difficultés à se joindre, la réticence des patients... ? L'amélioration de cette coordination est pourtant primordiale et semble un objectif simple et atteignable en soins 
primaires, sans pour autant recourir à un réseau. L'utilisation plus systématique de la visite de préreprise prévue par le Code de la Sécurité sociale pourrait être un élément de réponse à cette carence.

Une des limites de cette étude est le type de patients inclus, triés par la consultation multidisciplinaire. Ces patients ne sont pas représentatifs de l'ensemble des lombalgiques chroniques, mais sont déjà invalidés professionnellement par leur lombalgie, et adressés au réseau, dans un objectif de rééducation active et de maintien dans l'emploi. Les médecins généralistes, qui les ont adressés au réseau et ont été interrogés dans cette étude, sont eux aussi sélectionnés puisqu'ils connaissent ou utilisent déjà celui-ci.

L'organisation d'une réponse multidisciplinaire et la réalisation d'un réentraînement à l'effort sont actuellement surtout possibles dans des structures hospitalières ou dans le cadre de réseaux de soins. Ces modes de prise en charge ne concernent actuellement qu'une faible proportion des patients lombalgiques chroniques. Il est donc nécessaire de mieux définir des critères d'orientation vers ces structures et de diffuser les pratiques auprès des acteurs de soins primaires euxmêmes.

Les résultats obtenus permettent de dégager des axes d'amélioration et des pistes d'études ultérieures. La durée de l'arrêt de travail, la répétition des examens complémentaires et des avis spécialisés, la prescription de plus de 30 séances de kinésithérapie sont sans doute des indicateurs de la complexité de la situation biopsychosociale devant inciter à une orientation du patient. Une étude suisse montre l'intérêt d'associer un score de complexité médicale à la durée d'arrêt de travail, pour prédire l'efficacité de la prise en charge [36]. Il paraîtrait également intéressant de mieux définir la façon dont les médecins généralistes explorent le contexte psycho-socioprofessionnel des lombalgiques et par quels facteurs psychocomportementaux les patients arrivent à faire face ou non à ces difficultés [16].

L'amélioration des pratiques ne passe pas systématiquement par un réseau, mais la coordination entre les différents acteurs, médecins traitants, médecins du travail, médecins spécialistes et kinésithérapeutes, semble indispensable pour proposer une prise en charge cohérente, dans l'objectif de maintien dans l'emploi et de respect des recommandations. Des éléments comme le pourcentage de contacts médecin traitant/médecin du travail ou la présence de bilans kinésithérapiques dans les dossiers médicaux pourraient être des indicateurs de l'impact des formations continues sur ces thèmes. En amont de cette prise en charge des lombalgiques chroniques, la définition des critères et de scores prédictifs, permettant de prévenir précocement la chronicisation doit être approfondie [38].

\subsection{Conclusion}

Les lombalgiques chroniques suivent un parcours de soin comprenant de nombreux actes médicaux, paramédicaux et arrêts de travail. Le suivi de ces patients avant leur inclusion dans un réseau de réadaptation pluridisciplinaire est long, alors que les chances de reprise d'un travail sont liées à la rapidité d'une prise en charge adaptée et de la reprise de l'activité. Pour raccourcir ce délai, une meilleure connaissance par les généralistes de ces prises en charge et des critères d'orientation vers celles-ci, paraît nécessaire. Il semble également indispensable de déterminer plus précisément les facteurs prédisposant à l'invalidité, afin de dépister avant leur chronicisation les patients nécessitant un recours au réseau, sans pour autant surcharger celui-ci.

\section{Remerciements}

Ce travail a benéficié d'un financement par l'URCAM des Pays de la Loire.

\section{References}

[1] Abenhaim L, Rossignol M, Valat JP, Nordin M, Avouac B, Blotman F, et al. The role of activity in the therapeutic management of back pain. Report of the International Paris Task Force on Back Pain. Spine 2000;25:1S-33S

[2] Agence Nationale d'Accréditation et d'Évaluation en santé. Diagnostic, prise en charge et suivi des malades atteints de lombalgie chronique. 2000.

[3] ANAES, agence nationale d'accréditation et d'évaluation en santé. Évaluation des réseaux de soins bilan de l'existant et cadre méthodologique 2001.

[4] Andersson GB. Epidemiological features of chronic low-back pain. Lancet 1999;354:581-5. Review.

[5] Andersson GB, Svensson HO, Oden A. The intensity of work recovery in low back pain. Spine 1983;8:880-4.

[6] Arnau JM, Vallano A, Lopez A, Pellisé F, Delgado MJ, Prat N. A critical review of guidelines for low back pain treatment. Eur Spine J 2006;15(5):543-53. Epub 2005 Oct 11.

[7] Balague F, Cedraschi C. Radiological examination in low back pain patients: anxiety of the patient? Anxiety of the therapist? Joint Bone Spine 2006;73:508-13.

[8] Bazin T, Allaert F, Fuseiller A, Perles P. Étude du retentissement socioéconomique de la lombalgie chronique en pratique quotidienne de médecine générale. Rhumatologie 1998;50:95-101.

[9] Bishop PB, Wing PC. Compliance with clinical practice guidelines in family physicians managing worker's compensation board patients with acute lower back pain. Spine J 2003;3:442-50.

[10] Bontoux L, Roquelaure Y, Billabert C, Dubus V, Sancho PO, Colin D, et al. Étude du devenir à un an de lombalgiques chroniques inclus dans un programme associant reconditionnement à l'effort et action ergonomique. Recherche de facteurs prédictifs de retour et de maintien au travail. Ann Readapt Med Phys 2004;47:563-72.

[11] Chaory K, Rannou F, Fermanian J, Genty M, Rosenberg S, Billabert C, et al. Impact de programmes de restauration fonctionnelle sur les peurs, croyances et conduites d'évitement du lombalgique chronique. Ann Readapt Med Phys 2004;47:93-7.

[12] Coudeyre E, Rannou F, Tubach F, Baron G, Coriat F, Brin S, et al. General practitioners' fear-avoidance beliefs influence their management of patients with low back pain. Pain 2006;124(3):330-7.

[13] Fayad F, Lefevre-Colau MM, Poiraudeau S, Fermanian J, Rannou F, Wlodyka DS, et al. Chronicité, récidive et reprise du travail dans la lombalgie : facteurs communs de pronostic. Ann Readapt Med Phys 2004;47(4):179-89.

[14] Foltz V, St Pierre Y, Rozenberg S, Rossignol M, Bourgeois P, Joseph L, et al. Use of complementary and alternative therapies by patients with selfreported chronic back pain: a nationwide survey in Canada. Joint Bone Spine 2005;72:571-7.

[15] Frymoyer JW, Cats-Baril WL. An overview of the incidences and costs of low back pain. Orthop Clin North Am 1991;22(2):263-71.

[16] Genet F, Lapeyre E, Schnitzler A, Hausseguy A, D'Apolito AC, Lafaye de Michaux R, et al. Évaluation psychocomportementale dans la lombalgie chronique. Ann Readapt Med Phys 2006;49:226-33. 
[17] Gepner P, Charlot J, Avouac B, Pierron D, Pireault J, Scherding F, et al. Lumbago. Socioeconomic, epidemiological and medicolegal aspects. Rev Rhum Ed Fr 1994;61:5S-7S.

[18] Goupille P, Hercek A, Marre JP. Enquête sur la prise en charge de la lombalgie en médecine générale. Rev Prat Med Gen 2004;18:505-9.

[19] Guzmán J, Esmail R, Karjalainen K, Malmivaara A, Irvin E, Bombardier C. Multidisciplinary bio-psycho-social rehabilitation for chronic low-back pain. Cochrane Database Syst Rev 2007;18(2). CD000963. Review.

[20] Haumesser D, Becker P, Grosso-Lebon B, Weill G. Aspects médicaux, sociaux et économiques de la prise en charge des lombalgiques chroniques. Rev Med Assurance Mal 2004;35(1):27-36.

[21] Haut Comité de la Santé publique. La santé en France, rapport général. La documentation française. Paris. novembre 1994:276-7.

[22] Hourcade S, Treves R. Computed tomography in low back pain and sciatica. A retrospective study of 132 patients in the Haute-Vienne district of France. Joint Bone Spine 2002;69:589-96.

[23] Inserm, institut national de la santé et de la recherche médicale : lombalgies en milieu professionnel. Quels facteurs de risque et quelle prévention? Expertise Collective 2000.

[24] Jousset N, Fanello S, Bontoux L, Dubus V, Billabert C, Vielle B, et al. Effects of functional restoration versus $3 \mathrm{~h}$ per week physical therapy: a randomized controlled study. Spine 2004;29(5):487-93. discussion 494.

[25] Lafuma A, Fagnani F, Vautravers P. Management and cost of care for low back pain in primary care settings in France. Rev Rhum Engl Ed 1998;65(2):119-25.

[26] Mayer TG, Gatchel RJ, Kishino N, Keeley J, Capra P, Mayer H, et al. Objective assessment of spine function following industrial injury. A prospective study with comparison group and one-year follow-up. Spine 1985;10(6):482-93.

[27] Mayer TG, Smith SS, Keeley J, Mooney V. Quantification of lumbar function. Part 2: Sagittal plane trunk strength in chronic low-back pain patients. Spine 1985;10(8):765-72.

[28] Oldendick R, Coker AL, Wieland D, Raymond JI, Probst JC, Schell BJ, et al. Population-based survey of complementary and alternative medicine usage, patient satisfaction, and physician involvement. South Carolina Complementary Medicine Program Baseline Research Team. South Med J 2000;93(4):375-81.

[29] Poiraudeau S, Duvallet A, Barbosa Dos Santos I, Revel M. Efficacité à 1 an d'un programme de reconditionnement à l'effort proposé à des lombalgiques chroniques lourdement handicapés. Ann Readapt Med Phys 1999;42:33-41.
[30] Poiraudeau S, Rannou F, Revel M. Intérêts du réentraînement à l'effort dans la lombalgie : le concept de restauration fonctionnelle. Ann Readapt Med Phys 2007;50:419-24.

[31] Report of the Quebec Task Force on Spinal Disorders. Scientific approach to the assessment and management of activity-related spinal disorders. A monograph for clinicians. Spine 1987;12:S1-59.

[32] Roche G, Ponthieux A, Parot-Shinkel E, Jousset N, Bontoux L, Dubus V, et al. Comparison of a functional restoration program with active individual physical therapy for patients with chronic low back pain: a randomized controlled trial. Arch Phys Med Rehabil 2007;88:1229-35.

[33] Rossignol M. Working disability due to occupational back pain: three-year follow-up of 2300 compensated workers in Quebec. J Occup Med 1988;30:502-5.

[34] Rozenberg S. Le traitement médicamenteux de la lombalgie commune. Rev Rhum Ed Fr 2001;68:150-3.

[35] Rozenberg S, Allaert FA, Savarieau B, Perahia M, Valat JP. Compliance among general practitioners in France with recommendations not to prescribe bed rest for acute low back pain. Joint Bone Spine 2004;71(1):56-9.

[36] Scerri M, de Goumoens P, Fritsch C, Van Melle G, Stiefel F, So A. The INTERMED questionnaire for predicting return to work after a multidisciplinary rehabilitation program for chronic low back pain. Joint Bone Spine 2006;73:736-41.

[37] Société française de médecine générale, observatoire de la médecine générale, informations épidémiologiques sur les pathologies et leur prise en charge en ville. Principaux motifs de consultation en médecine générale/consultations pour lombalgie. http://omg.sfmg.org (2005).

[38] Valat JP, Goupille P, Rozenberg S, Urbinelli R, Allaert F, Spine Group of the Societe Francaise de Rhumatologie. Acute low back pain: predictive index of chronicity from a cohort of 2487 subjects. Joint Bone Spine 2000;67(5):456-61.

[39] Van den Hoogen HJ, Koes BW, van Eijk JT, Bouter LM, Deville W. On the course of low back pain in general practice: a one year follow up study. Ann Rheum Dis 1998;57:13-9.

[40] Van Tulder MW, Koes BW, Metsemakers JF, Bouter LM. Chronic low back pain in primary care: a prospective study on the management and course. Fam Pract 1998;15:126-32.

[41] Van Tulder MW, Ostelo RW, Vlaeyen JW, Linton SJ, Morley SJ, Assendelft WJ. Behavioural treatment for chronic low back pain. Cochrane Database Syst Rev )2000;(2). CD002014. Review.

[42] Webster BS, Courtney TK, Huang YH, Matz S, Christiani DC. Physicians' initial management of acute low back pain versus evidence-based guidelines. Influence of sciatica. J Gen Intern Med 2005;20:1132-5. 